\title{
The haemagglutinin of Clostridium botulinum type $C$ progenitor toxin plays an essential role in binding of toxin to the epithelial cells of guinea pig small intestine, leading to the efficient absorption of the toxin
}

\author{
Yukako Fujinaga, ${ }^{1}$ Kaoru Inoue, ${ }^{1}$ Sadahiro Watanabe, ${ }^{2}$ Kenji Yokota, ${ }^{1}$ \\ Yoshikazu Hirai, ${ }^{1}$ Eiko Nagamachi ${ }^{3}$ and Keiji Oguma ${ }^{1}$
}

Author for correspondence: Keiji Oguma. Tel/Fax: +81 86235 7162. e-mail: kuma@med.okayama-u.ac.jp

\footnotetext{
1 Department of Bacteriology, Okayama University Medical School, 2-5-1 Shikata-cho, Okayama 700, Japan

2 Kobe City College of Nursing, 3-1 Gakuennishimachi, Nishi-ku, Kobe 651, Japan

3 Department of Nursing, School of Health Science, Kibi International University, 8 Iga-machi, Takahashi, Okayama 716, Japan
}

\begin{abstract}
Binding of the purified type $C 75$ (neurotoxin), $12 S$ and 165 botulinum toxins to epithelial cells of ligated small intestine or colon of the guinea pig (in vivo test) and to pre-fixed gastrointestinal tissue sections (in vitro test) was analysed. The 165 toxin bound intensely to the microvilli of epithelial cells of the small intestine in both in vivo and in vitro tests, but did not bind to cells of the stomach or colon. The neurotoxin and 125 toxin did not bind to epithelial cells of the small intestine or to cells of the stomach or colon. Absorption of the toxins was assessed by determining the toxin titre in the sera of guinea pigs 6-8 $\mathrm{h}$ after the intra-intestinal administration of the toxins. When the 165 toxin [1 $\times 10^{5}$ minimum lethal dose (MLD)] was injected, 200-660 $\mathrm{MLD} \mathrm{ml}^{-1}$ was detected in the sera, whereas when the 125 toxin $\left(2 \times 10^{5} \mathrm{MLD}\right)$ or 75 toxin $\left(2 \times 10^{5} \mathrm{MLD}\right)$ was injected, little toxin activity was detected in the sera. Therefore, the haemagglutinin of type $\mathrm{C} 16 \mathrm{~S}$ toxin is apparently very important in the binding and absorption of botulinum toxin in the small intestine.
\end{abstract}

Keywords: haemagglutinin, Clostridium botulinum, toxin binding, absorption

\section{INTRODUCTION}

Botulinum neurotoxin, a protein of approximately $150 \mathrm{kDa}$, is produced in serologically distinct forms (types $\mathrm{A}-\mathrm{G}$ ) by the Gram-positive spore-forming bacterium Clostridium botulinum. The neurotoxin produced by the bacterium is in the form of a stable complex due to its association with non-toxic proteins. The complex, designated progenitor toxin, is found in three forms: $12 \mathrm{~S}$ toxin (molecular mass $\sim 300 \mathrm{kDa}$ ), $16 \mathrm{~S}$ toxin $(\sim 500 \mathrm{kDa})$ and $19 \mathrm{~S}$ toxin $(\sim 900 \mathrm{kDa})$ (Sugii et al., 1977a, b; Ohishi \& Sakaguchi, 1980). Type A progenitor toxin is composed of all three forms; type B, $\mathrm{C}$ and $\mathrm{D}$ toxins are composed of two forms, namely $12 \mathrm{~S}$ and $16 \mathrm{~S}$; type $\mathrm{E}$ and $\mathrm{F}$ toxins are composed of a single

\footnotetext{
Abbreviations: $D A B, 3,3^{\prime}$-diaminobenzidine tetrahydrochloride; $H A$, haemagglutinin; MLD, minimum lethal dose; PLP, periodate/lysine/ paraformaldehyde.
}

form, 12S; and type $G$ toxin is composed of a single form, 16S. Comparative genetic and biochemical analyses of these progenitor toxins have been facilitated by cloning and sequencing the representative operons encoding them and by purifying the corresponding toxins (Kimura et al., 1990; Tsuzuki et al., 1990, 1992; Fujinaga et al., 1994; Hauser et al., 1994; Fujita et al., 1995; Minton, 1995; Oguma et al., 1995; Ohyama et al., 1995; Henderson et al., 1996; Inoue et al., 1996). From these studies, the following conclusions were drawn. The $12 \mathrm{~S}$ toxin consists of a neurotoxin and a non-toxic component having no haemagglutinin (HA) activity, designated non-toxic non-HA. The $16 \mathrm{~S}$ toxin consists of a neurotoxin, a non-toxic non-HA, and a $\mathrm{HA}$, associated in the ratio $1: 1: 2$. The molecular mass of the non-toxic non-HA is $120-140 \mathrm{kDa}$, but the non-toxic non-HA of the $12 \mathrm{~S}$ toxin is dissociated into $105-130 \mathrm{kDa}$ and 10-15 kDa components on SDS-PAGE with or without 2-mercaptoethanol. The HA consists of subcomponents having molecular mass values of approximately 53, 33, 
22-23 and $17 \mathrm{kDa}$ in type C (Fujinaga et al., 1994) and $\mathrm{D}$ (Ohyama et al., 1995) toxins, and 52, 35, 19-20 and $15 \mathrm{kDa}$ in type A toxin (Fujita et al., 1995; Inoue et al., 1996). The type A $19 S$ toxin consists of the same protein components as the $16 \mathrm{~S}$ toxin; it is presumed to be a dimer of the $16 \mathrm{~S}$ toxin conjugated through HA-35 molecules (Inoue et al., 1996).

Human and animal food-borne botulism is caused by ingestion of food or feed containing the progenitor toxin. The orally ingested progenitor toxin is absorbed from the upper small intestine into the lymphatic system (Sugii et al., 1977b); it then enters the bloodstream and reaches peripheral nerves, where neurological dysfunction is elicited. The non-toxic components are considered to be very important in the development of food poisoning because they protect the neurotoxin from the acidity and proteases in the digestive tract (Sugii et al., 1977a, b; Ohishi \& Sakaguchi, 1980). It has also been reported that the dissociation of the type $\mathrm{B} 16 \mathrm{~S}$ toxin into neurotoxin and non-toxic components occurs in a buffer solution of $\mathrm{pH}>7 \cdot 0$, but does not occur in rat intestinal juice of $\mathrm{pH} 7 \cdot 0$ (Sugii et al., 1977a).

Despite increased understanding of the biochemistry of the progenitor toxin, the role of the non-toxic components in oral toxicity has not been fully clarified. The current study reports that the HA of the type C $16 \mathrm{~S}$ toxin binds to epithelial cells of the upper small intestine of guinea pigs, and that only the $16 \mathrm{~S}$ toxin is efficiently absorbed there.

\section{METHODS}

Toxins. The type $\mathrm{C} 16 \mathrm{~S}$ and $12 \mathrm{~S}$ toxins, and the $7 \mathrm{~S}$ (neurotoxin) toxin were highly purified from the culture fluid of $C$. botulinum type C strain Stockholm (C-ST) according to the procedure previously employed for purifying type A toxins (Inoue et al., 1996). The toxins were precipitated by $50 \%$ saturation with ammonium sulphate. The harvested precipitates were dialysed against $50 \mathrm{mM}$ sodium acetate buffer $(\mathrm{pH} 4 \cdot 2)$, and then applied on to an SP-Toyopearl $650 \mathrm{M}$ column. The $16 \mathrm{~S}$ and $12 \mathrm{~S}$ toxins separated by this column chromatographic procedure were further purified by gel filtration on a Sephacryl S-300 column, and by densitygradient centrifugation on a $5-20 \%$ sucrose gradient at $\mathrm{pH} 6 \cdot 0$. The $7 \mathrm{~S}$ toxin was isolated from the $16 \mathrm{~S}$ toxin thus obtained by density-gradient centrifugation on a $5-20 \%$ sucrose gradient at $\mathrm{pH} 8 \cdot 8$. Toxins were dissolved in toxin dilution buffer $(20 \mathrm{mM}$ sodium phosphate buffer, pH 6.0, containing $0 \cdot 2 \%, \mathrm{w} / \mathrm{v}$, gelatin) at a concentration of about $1 \mathrm{mg} \mathrm{ml}^{-1}$ and stored frozen at $-80^{\circ} \mathrm{C}$ until used.

Antisera. Two previously described antisera against the purified type $C$ neurotoxin and the non-toxic components containing both HA and non-toxic non-HA (Oguma et al., 1980) were used in this study. An antiserum against the purified type $\mathrm{C} 16 \mathrm{~S}$ toxin was produced in a rabbit by the same procedure described previously by Oguma et al. (1980). For the binding inhibition experiments, the immunoglobulin fractions obtained by DEAE-cellulose chromatography from these antisera were employed (Tsuzuki et al., 1988).

Animals. Female Hartley strain guinea pigs (Shimizu Laboratory Supplies) were used at between 8 and 12 weeks of age
$(400-600 \mathrm{~g})$. The animals were not fed for $24 \mathrm{~h}$ prior to use, with water given freely. The experimental protocols were approved by the Animal Experiment Control Committee of Okayama University Medical School, and were in accordance with its guidelines. The minimum number of guinea pigs necessary to obtain valid results was used.

Toxin binding to ligated intestinal loops (in vivo test). Guinea pigs were anaesthetized by intraperitoneal injection of sodium pentobarbital, and the abdomen was opened along the midline. One ligated intestinal loop $(3-4 \mathrm{~cm}$ in length) was made in the upper small intestine $(3-8 \mathrm{~cm}$ from the pylorus), lower small intestine $(2-7 \mathrm{~cm}$ from the caecum), proximal colon $(2-7 \mathrm{~cm}$ from the caecum) and distal colon $(3-8 \mathrm{~cm}$ from the anus). Care was taken to leave the blood supply intact. Each loop was inoculated with $0.4-0.8 \mathrm{ml}$ toxin solution $(20 \mathrm{nM})$ by a 27 gauge needle, and a second tie was made to isolate the site of injection. Care was taken to maximize the distribution of the toxin solution throughout the loop. Loops were incubated for $1 \mathrm{~h}$ in the abdominal cavity, while the guinea pigs were kept warm and under anaesthesia. In the case of the stomach, $1 \mathrm{ml}$ of the toxin solution $(20 \mathrm{nM})$ was orally inoculated by a feeding needle, and reacted for $1 \mathrm{~h}$.

Thereafter, the loops and stomach were excised from the guinea pig, opened, briefly washed in two changes of ice-cold PBS $(0.149 \mathrm{M} \mathrm{NaCl} ; 0.01 \mathrm{M}$ sodium phosphate; $\mathrm{pH} 6.0)$, and fixed in periodate/lysine/paraformaldehyde (PLP) fixative for $5 \mathrm{~h}$ at $4^{\circ} \mathrm{C}$ (Yoshimura et al., 1980). The tissues were dehydrated and paraffin-embedded before cutting 5 - $\mu \mathrm{m}$-thick sections. The sections were deparaffinized, hydrated, rinsed in PBS, and incubated with $0.3 \% \mathrm{H}_{2} \mathrm{O}_{2}$ in methanol for $30 \mathrm{~min}$ at room temperature to inactivate the endogenous peroxidase. After washing with $\mathrm{PBS} / 0 \cdot 1 \%$ Triton X-100, they were incubated with $1 \mathrm{M}$ glycine in PBS $/ 0 \cdot 1 \%$ Triton X-100 for $1 \mathrm{~h}$ at room temperature to block free aldehyde groups generated by treatment with the fixative. After washing with PBS $/ 0 \cdot 1 \%$ Triton X-100, the sections were first incubated with $3 \%$ normal goat serum for $1 \mathrm{~h}$ at room temperature to block the non-specific reaction, and then with the properly diluted rabbit anti-type $\mathrm{C} 16 \mathrm{~S}$ toxin in a humidity chamber at $4{ }^{\circ} \mathrm{C}$ overnight. Finally, they were treated with biotinylated goat anti-rabbit antibody (Vectastain Elite ABC kit; Vector Laboratories) at room temperature for $1 \mathrm{~h}$, and developed by using avidin-biotin peroxidase complexes (Vectastain Elite $A B C$ kit; Vector Laboratories) and DAB solution $\left(0.25 \mathrm{mg} 3,3^{\prime}-\right.$ diaminobenzidine tetrahydrochloride $\mathrm{ml}^{-1}$ and $0.002 \% \mathrm{H}_{2} \mathrm{O}_{2}$ in $25 \mathrm{mM}$ Tris/ $\mathrm{HCl}$ buffer, $\mathrm{pH} 7 \cdot 2$ ) according to the manufacturer's instructions. Sections were then counterstained with haematoxylin and examined using a light microscope.

Toxin binding to pre-fixed sections of intestine (in vitro test). Samples of the stomach, the upper and lower small intestine, and the proximal and distal portions of the colon were removed from the anaesthetized guinea pigs. All samples were fixed with a solution of $4 \%$ paraformaldehyde in $0 \cdot 1 \mathrm{M}$ sodium phosphate buffer $(\mathrm{pH} 7 \cdot 2)$ for $24 \mathrm{~h}$ at $4{ }^{\circ} \mathrm{C}$, dehydrated and embedded in paraffin, and 5 - $\mu$ m-thick sections were cut. The sections were deparaffinized, hydrated, rinsed in PBS ( $\mathrm{pH} 7.2$ ) and incubated with $1 \mathrm{M}$ glycine in PBS ( $\mathrm{pH} 7.2$ ) for $1 \mathrm{~h}$ at room temperature. After washing with PBS ( $\mathrm{pH} 6.0$ ), they were incubated with the toxin solutions $(2 \mathrm{nM})$ in a humidity chamber for $1 \mathrm{~h}$ at room temperature. To diminish the non-specific binding of the toxin, the sections were washed in six changes of PBS $(\mathrm{pH} 6 \cdot 0) / 0 \cdot 1 \%$ Triton X-100 for $10 \mathrm{~min}$. They were then incubated with $0 \cdot 3 \% \mathrm{H}_{2} \mathrm{O}_{2}$ in methanol for $30 \mathrm{~min}$ at room temperature. After washing with PBS $(\mathrm{pH} 6 \cdot 0) / 0 \cdot 1 \%$ Triton $\mathrm{X}-100$, the sections were incubated 
with $3 \%$ normal goat serum for $1 \mathrm{~h}$ at room temperature, and then stained with the diluted rabbit anti-type C $16 \mathrm{~S}$ toxin, followed by biotinylated goat anti-rabbit antibody, avidinbiotin peroxidase complexes and DAB substrate. Sections were counterstained with haematoxylin and examined with a light microscope.

\section{Inhibition assays}

(i) Antibody inhibition. The $16 \mathrm{~S}$ toxin (final concentration $1 \mu \mathrm{g} \mathrm{ml}^{-1}$ ) was incubated for $1 \mathrm{~h}$ at $25^{\circ} \mathrm{C}$ with purified anti$16 \mathrm{~S}$ (final concentration $30 \mu \mathrm{g} \mathrm{ml}^{-1}$ ), anti-non-toxic components (final concentration $30 \mu \mathrm{g} \mathrm{ml}^{-1}$ ) or anti-neurotoxin immunoglobulins (final concentration $30 \mu \mathrm{g} \mathrm{ml}^{-1}$ ), and then the mixtures were reacted with the pre-fixed sections. The binding assay was then performed as described above.

(ii) Neuraminidase-treated sections. Tissue sections were treated with Arthrobacter ureafaciens neuraminidase (highly purified preparation containing no protease, $N$-acetylneuraminic acid aldolase or glycosidase; Nacalai tesque) at $3 \mathrm{U} \mathrm{ml}^{-1}$ according to the procedure of Caldero et al. (1988). Briefly, the sections were incubated with neuraminidase at $37^{\circ} \mathrm{C}$ in a humidified environment for $12 \mathrm{~h}$. Following this, the sections were incubated with $1 \mathrm{M}$ glycine in PBS $/ 0 \cdot 1 \%$ Triton X-100 and then the toxin-binding test was performed.

Immunoelectron microscopy. Toxin $(20 \mathrm{nM})$ or toxin dilution buffer was injected in the ligated intestinal loops and reacted in the same way as described for the in vivo test. The ligated areas were resected out and fixed with $4 \%$ paraformaldehyde and $0.1 \%$ glutaraldehyde in $0.1 \mathrm{M}$ sodium phosphate buffer $\left(\mathrm{pH} 7 \cdot 2\right.$ ) for more than $6 \mathrm{~h}$ at $4{ }^{\circ} \mathrm{C}$. After washing with PBS, the intestine was cut into $20-\mu \mathrm{m}$-thick cross-sections with a vibratome (Microslicer DTK-1000; Dousaka). The resultant sections were pre-incubated with $0.3 \% \mathrm{H}_{2} \mathrm{O}_{2}$ in methanol for $30 \mathrm{~min}$, with $1 \mathrm{M}$ glycine and $3 \%$ normal goat serum each for $1 \mathrm{~h}$ at room temperature, and then reacted with rabbit antitype $\mathrm{C} 16 \mathrm{~S}$ toxin at $4{ }^{\circ} \mathrm{C}$ overnight. Thereafter, the sections were successively reacted with biotinylated goat anti-rabbit antibody, avidin-biotin peroxidase complexes, and DAB solution same as the staining method for the light microscopy, and then reacted with $1 \% \mathrm{OsO}_{4}$ for $1 \mathrm{~h}$. After dehydration with an acetone series, the samples were embedded in epoxy resin. Ultrathin sections were cut with an ultramicrotome (Sorval MT-5000) and observed under a transmission electron microscope (JEM 100-CX) operated at $80 \mathrm{kV}$.

Intra-intestinal administration of toxins to guinea pigs. Guinea pigs were anaesthetized with Sevoflurane (Maruishi Seiyaku) and the intestine was approached via a small midline incision. A $0.4 \mathrm{ml}$ dose of toxin was injected into the upper small intestine $(3-4 \mathrm{~cm}$ from the pylorus) with a 27 gauge needle. Care was taken not to spill the toxin into the abdominal cavity. After the incision was sutured, the guinea pigs were kept in restraining cages. The guinea pigs were killed after $6-8 \mathrm{~h}$, and blood was collected to analyse the amount of toxins absorbed.

Tests for stability of the toxin in digestive juice. Digestive juice (actually a mixture of gastric, bile, pancreatic and intestinal juices; $\mathrm{pH}$ of about 8.0 ) was obtained from two guinea pigs separately as follows. A guinea pig was anaesthetized with Sevoflurane. The intestine was approached via a small midline incision and then the upper small intestine (about $3 \mathrm{~cm}$ below the major duodenal papilla) was ligated. After the incision was stitched, the guinea pig was kept in a restraining cage for $8 \mathrm{~h}$. After the guinea pig was killed, the digestive juice that had accumulated in the duodenum and stomach was taken out. The collected intestinal juice was centrifuged at $3000 \mathrm{~g}$ for $10 \mathrm{~min}$ and the supernatant fluid was used for experiments. Twenty microlitres of the $16 \mathrm{~S}, 12 \mathrm{~S}$ or $7 \mathrm{~S}$ toxin, having $10^{4}$ times the minimum lethal dose (MLD) for mice, was mixed with $380 \mu \mathrm{l}$ digestive juice and incubated for up to $8 \mathrm{~h}$ at $35^{\circ} \mathrm{C}$. The toxicity of the samples was then determined in mice.

Other procedures. Toxicity (MLD) of the preparations was determined by injecting the diluted samples into mice intraperitoneally as reported previously by Inoue et al. (1996). Protein concentration was determined by the method of Bradford as described previously by Inoue et al. (1996).

\section{RESULTS}

\section{Reactivities of the anti-type C $16 \mathrm{~S}$ toxin serum with $16 S, 12 S$ and $7 S$ toxins differed}

Since binding of the toxins to the epithelial cells was studied by using anti-type C $16 \mathrm{~S}$ toxin antiserum as a primary antibody, the reactivity of this antiserum with the $16 \mathrm{~S}, 12 \mathrm{~S}$ or $7 \mathrm{~S}$ toxin was first evaluated. Each toxin ( $2 \mu \mathrm{l} 5 \mathrm{nM}$ solution) was dot-blotted on a nitrocellulose membrane and then the serial tenfold- and twofolddiluted anti-16S toxin serum was reacted, followed by the secondary antibody and the substrate. The reactivities of this antiserum with the $16 \mathrm{~S}, 12 \mathrm{~S}$ and $7 \mathrm{~S}$ toxins were slightly different. Therefore, the following binding experiments in vivo and in vitro were performed using $0.25 \times 10^{-3}$ -, $0.5 \times 10^{-3}$ - or $1 \times 10^{-3}$-diluted sera to detect the $16 \mathrm{~S}, 12 \mathrm{~S}$ or $7 \mathrm{~S}$ toxins, respectively.

\section{5 toxin binds selectively to epithelial cells of the upper small intestine (in vivo test)}

The intestinal loops of guinea pigs were ligated and then reacted with $16 \mathrm{~S}, 12 \mathrm{~S}$ or $7 \mathrm{~S}$ toxin. Binding of the toxins to cells was determined by immunostaining. Fig. 1(a) illustrates the specific staining of oxidized 3,3'-diaminobenzidine corresponding to the $16 \mathrm{~S}$ toxin at the epithelial surface of the upper small intestine. The $16 \mathrm{~S}$ toxin bound weakly to the lower small intestine as compared to the upper region (Table 1). In other tissues, including the stomach (Fig. 1c; Table 1) and colon (Fig. 1d; Table 1 ), little of the $16 \mathrm{~S}$ toxin attached to the cells. None of the loops inoculated with the toxin dilution buffer (negative control) were stained (Fig. 1b, upper small intestine). The same binding profile of the $16 \mathrm{~S}$ toxin was obtained by using anti-non-toxic components antiserum instead of anti-16S toxin serum. Binding of the toxin was also detected by using anti-neurotoxin antiserum. When the tissues were fixed in $4 \%$ paraformaldehyde, the intensity of the $16 \mathrm{~S}$ toxin binding was considerably diminished. In the cases of the $7 \mathrm{~S}$ and $12 \mathrm{~S}$ toxins, no binding was observed to any portions of the digestive tract (Table 1). These data reveal that the $16 \mathrm{~S}$ toxin can bind strongly to the epithelial surface of only the upper small intestine.

\section{$16 S$ but not $12 S$ or 75 toxin binds to pre-fixed sections of intestine (in vitro test)}

To determine the progenitor toxin component(s) required for binding to the epithelial surface of the upper small intestine, the binding test in vitro was undertaken. 

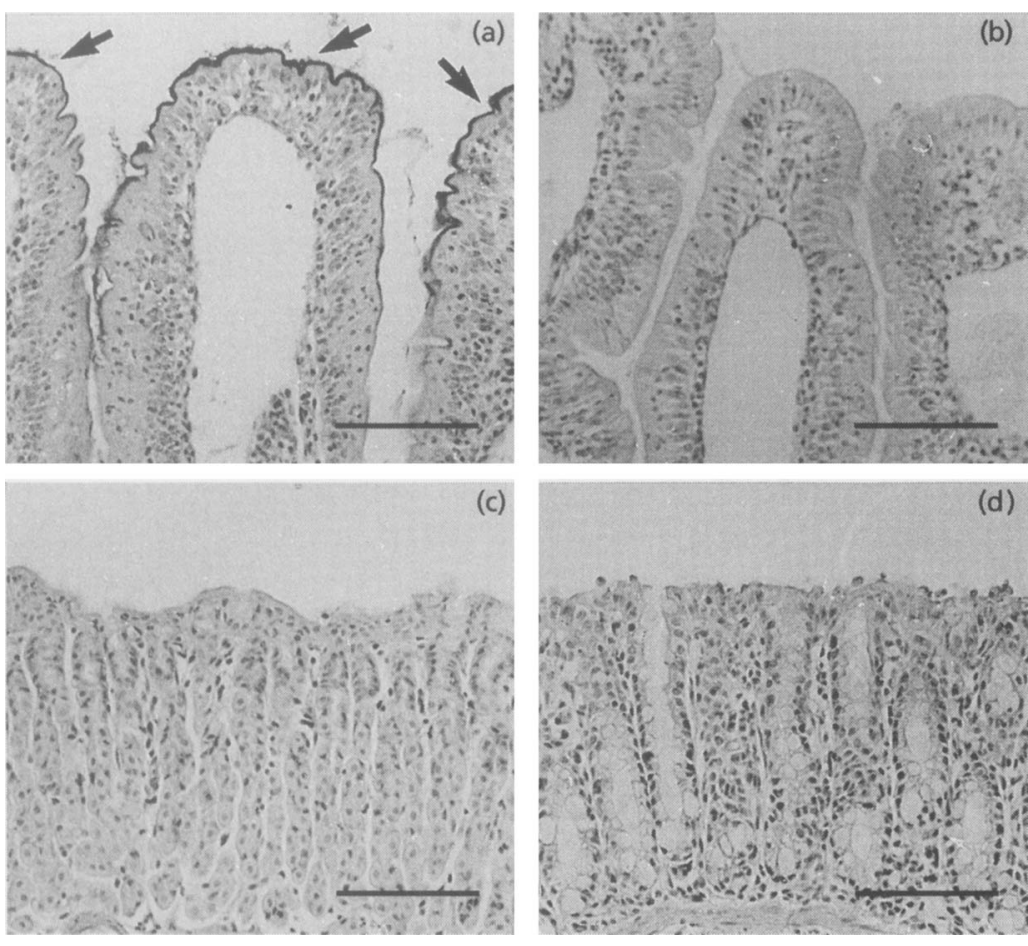

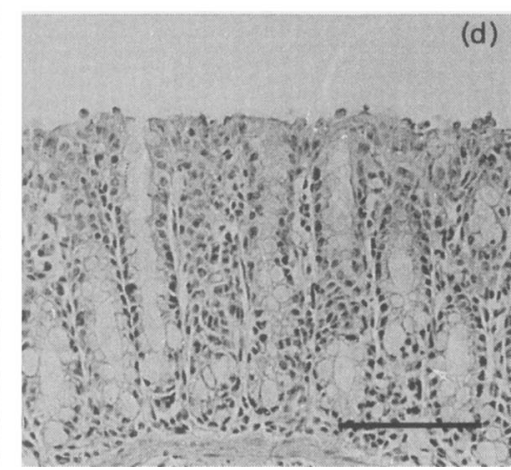

Fig. 1. Localization of type $C 165$ toxin in vivo. (a) Guinea pig upper small intestine incubated with type $C 165$ toxin $\left(10 \mu \mathrm{g} \mathrm{ml}^{-1}\right.$. $20 \mathrm{nM})$. Arrows point to the location of the toxin. (b) Upper small intestine incubated with toxin dilution buffer (not exposed to toxin, but otherwise treated identically). (c) Stomach incubated with type $C 165$ toxin $\left(10 \mu \mathrm{g} \mathrm{ml}^{-1}\right)$. (d) Colon incubated with type $C 165$ toxin $\left(10 \mu \mathrm{g} \mathrm{ml}^{-1}\right)$. The same results were obtained in three repeats of this experiment using three guinea pigs, and each was done in duplicate. Bars, $100 \mu \mathrm{m}$.

\section{Table 1. Binding of type $C$ toxins to epithelial cells of the gastrointestinal tract}

Assays were performed in at least three independent experiments (using three guinea pigs), and each was done in duplicate, giving the same results each time. Intensity of staining: - , absent; \pm , traces; + , weak $;++$, intense. For an example of ++ staining, see Fig. 1(a).

\begin{tabular}{|c|c|c|c|c|c|c|c|}
\hline & \multicolumn{2}{|r|}{ Toxin } & \multicolumn{5}{|c|}{ Binding } \\
\hline & \multirow[t]{2}{*}{ Type } & \multirow[t]{2}{*}{ Concn } & \multirow[t]{2}{*}{ Stomach ${ }^{*}$} & \multicolumn{2}{|c|}{ Small intestine } & \multicolumn{2}{|c|}{ Colon } \\
\hline & & & & Upper & Lower & Proximal & Distal \\
\hline In vivo & $16 S$ & $10 \mu \mathrm{g} \mathrm{ml}^{-1}(20 \mathrm{nM})$ & - & $+t$ & + & \pm & \pm \\
\hline \multirow[t]{2}{*}{ (ligated intestine) } & $12 \mathrm{~S}$ & $6 \mu \mathrm{g} \mathrm{ml}^{-1}(20 \mathrm{nM})$ & - & - & - & - & - \\
\hline & 75 & $3 \mu \mathrm{g} \mathrm{m}^{-1}(20 \mathrm{nM})$ & - & - & - & - & - \\
\hline In vitro & $16 \mathrm{~S}$ & $1 \mu \mathrm{g} \mathrm{ml}^{-1}(2 \mathrm{nM})$ & \pm & ++ & ++ & \pm & \pm \\
\hline \multirow[t]{2}{*}{ (section) } & $12 \mathrm{~S}$ & $0.6 \mu \mathrm{g} \mathrm{ml}^{-1}(2 \mathrm{nM})$ & ND & - & - & - & - \\
\hline & $7 \mathrm{~S}$ & $0.3 \mu \mathrm{g} \mathrm{ml}^{-1}(2 \mathrm{nM})$ & ND & - & - & - & - \\
\hline
\end{tabular}

*Toxin preparations $(1 \mathrm{ml})$ were orally administered.

In this assay, each segment of the digestive tract of healthy guinea pigs was fixed in $4 \%$ paraformaldehyde instead of the PLP fixative, because the PLP fixative modifies the carbohydrate chains in the tissue, which might have an adverse influence on the binding of toxin. In the pre-fixed sections of the upper and lower small intestine, the $16 \mathrm{~S}$ toxin showed intense binding to brush border and goblet cells, whereas $12 \mathrm{~S}$ and $7 \mathrm{~S}$ toxins did not show any binding to any sites (Table 1 ). In sections of the stomach and colon, all these toxins could not obviously bind to any sites (Table 1 ). The same binding property of the $16 \mathrm{~S}$ toxin was observed by using antinon-toxic components serum instead of the anti-16S toxin serum.

\section{Antibodies or neuraminidase treatment inhibit binding of the $16 \mathrm{~S}$ toxin}

The effects of pre-incubation of the toxins with antitoxin antibodies and of pre-treatment of the tissue sections with neuraminidase were examined. Pre-incubation of the $16 \mathrm{~S}$ toxin with the purified anti-16S 

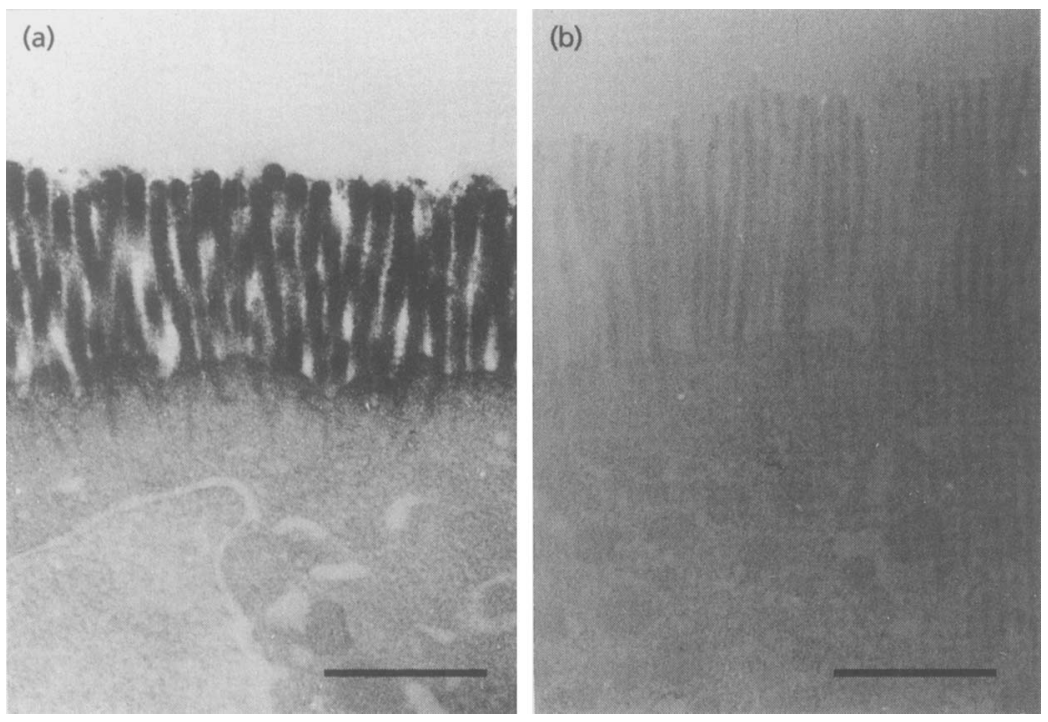

Fig. 2. Electron micrographs comparing type C 16S-treated intestinal epithelium and normal epithelium. (a) Epithelial cells from a ligated intestinal loop subjected to 165 toxin $\left(10 \mu \mathrm{g} \mathrm{mi}^{-1}, 20 \mathrm{nM}\right)$ for $1 \mathrm{~h}$. (b) Epithelial cells in an adjacent intestinal loop injected with toxin dilution buffer. The same results were obtained in two repeats of this experiment using different guinea pigs. Bars, $1 \mu \mathrm{m}$.

toxin immunoglobulins or anti-non-toxic components immunoglobulins resulted in an apparent inhibition of the binding to brush border and goblet cells, whereas pre-incubation of the $16 \mathrm{~S}$ toxin with the purified anti-7S immunoglobulin did not influence the toxin-binding properties. Neuraminidase treatment of the tissue sections prior to incubation with the toxin completely abolished binding of the $16 \mathrm{~S}$ toxin to the luminal surface of intestinal epithelial cells. These inhibition assays were repeated three times using tissue sections from three different guinea pigs; these gave the same results each time.

\section{Ultrastructural localization of the 165 toxin to the microvilli of the epithelial surface}

With the light microscope, the $16 \mathrm{~S}$ toxin was detected at the epithelial surface of the upper small intestine as mentioned above. To more precisely determine the toxin-binding site on the intestinal epithelial surface, an immunoenzymic labelling technique was used in conjunction with electron microscopy. The microvilli membranes were stained with electron-opaque reaction product (Fig. 2a), whereas no staining was observed in the control (Fig. 2b).

\section{5 but not 125 or 75 type $C$ toxin is absorbed in the intestine of guinea pigs}

Absorption of the toxins was assessed by determining the toxin titres in the sera of guinea pigs $6-8 \mathrm{~h}$ after the intra-intestinal administration of the toxins (Table 2). When the $16 \mathrm{~S}$ toxin $\left(1 \times 10^{5} \mathrm{MLD}\right)$ was injected, 200 $660 \mathrm{MLD} \mathrm{ml}^{-1}$ was detected in the serum, whereas when the $12 S$ toxin $\left(2 \times 10^{5} \mathrm{MLD}\right)$ or $7 \mathrm{~S}$ toxin $(2 \times$ $\left.10^{5} \mathrm{MLD}\right)$ was injected, little toxin activity was detected, i.e. $0.5 \mathrm{ml}$ of each threefold-diluted serum did not kill mice. The guinea pigs which received the $12 \mathrm{~S}$ or $7 \mathrm{~S}$ toxin intra-intestinally did not show signs of botulism during
Table 2. Absorption of type $C$ progenitor toxins from the small intestine

The toxin titre in the blood was determined by intraperitoneal injection into two mice. Assays for absorption of each type of the toxin were performed in three independent experiments (using three guinea pigs).

\begin{tabular}{|ccc|}
\hline & $\begin{array}{c}\text { Toxin (intra-intestinal } \\
\text { administration) }\end{array}$ & $\begin{array}{c}\text { Toxin titre in } \\
\text { blood }\left(\mathrm{MLD} \mathrm{ml}^{-1}\right)\end{array}$ \\
\hline Type & $\begin{array}{c}\text { Amount } \\
(\text { MLD in 0.4 ml) }\end{array}$ & \\
\hline $16 \mathrm{~S}$ & $1 \times 10^{5}$ & $\begin{array}{c}2 \times 10^{2}, 2 \times 10^{2}, \\
6.6 \times 10^{2} \\
\end{array}$ \\
$12 \mathrm{~S}$ & $2 \times 10^{5}$ & $<6,<6,<6$ \\
$7 \mathrm{~S}$ & $2 \times 10^{5}$ & $<6,<6,<6$ \\
\hline
\end{tabular}

this period, but those which received the $16 \mathrm{~S}$ toxin manifested severe botulism about $6 \mathrm{~h}$ after inoculation of the toxin.

When each of the $16 \mathrm{~S}, 12 \mathrm{~S}$ and $7 \mathrm{~S}$ toxins was injected in the ligated upper small intestine, all guinea pigs receiving these three types of type $C$ toxin manifested severe botulism about $2 \mathrm{~h}$ after the inoculation, and more than $200 \mathrm{MLD} \mathrm{ml}^{-1}$ was detected in the sera. It seemed that all forms of the type $C$ toxin spilled artificially through the damaged tissue caused by ligation of the intestine. Therefore, we consider that the ligated intestine system is not appropriate for toxin absorption experiments.

\section{$12 S$ and $7 \mathrm{~S}$ toxins are slightly less stable than $16 \mathrm{~S}$ toxin in digestive juice}

The stabilities of the different forms of type $\mathrm{C}$ toxin in the digestive juice of guinea pigs were tested (Table 3 ). The $16 \mathrm{~S}$ toxin was resistant to the digestive juice and 
Table 3. Stabilities of type $C$ toxins in digestive juice

The experiment was repeated twice using the digestive juices from different guinea pigs and gave essentially the same results. After incubation with digestive juice, each sample was diluted as indicated, then the toxicity was determined using two mice. D, Died; M, manifested a symptom of botulism; S, survived.

\begin{tabular}{|lrlll|}
\hline Toxin & $\begin{array}{c}\text { Sample } \\
\text { dilution }\end{array}$ & \multicolumn{3}{c|}{$\begin{array}{c}\text { Toxicity at time (h) after } \\
\text { incubation with digestive juice }\end{array}$} \\
\cline { 3 - 5 } & & 0 (control) & 2 & \multicolumn{1}{c|}{$\mathbf{2}$} \\
\hline \multirow{2}{*}{$16 \mathrm{~S}$} & $1 \times 10^{-3}$ & $\mathrm{D}, \mathrm{D}$ & $\mathrm{D}, \mathrm{D}$ & $\mathrm{D}, \mathrm{D}$ \\
& $1 \times 10^{-4}$ & $\mathrm{M}, \mathrm{M}$ & $\mathrm{M}, \mathrm{S}$ & $\mathrm{M}, \mathrm{M}$ \\
& $0.3 \times 10^{-4}$ & $\mathrm{~S}, \mathrm{~S}$ & $\mathrm{~S}, \mathrm{~S}$ & $\mathrm{~S}, \mathrm{~S}$ \\
& $1 \times 10^{-3}$ & $\mathrm{D}, \mathrm{D}$ & $\mathrm{D}, \mathrm{D}$ & $\mathrm{D}, \mathrm{D}$ \\
& $1 \times 10^{-4}$ & $\mathrm{D}, \mathrm{D}$ & $\mathrm{D}, \mathrm{M}$ & $\mathrm{D}, \mathrm{D}$ \\
& $0.3 \times 10^{-4}$ & $\mathrm{D}, \mathrm{M}$ & $\mathrm{D}, \mathrm{M}$ & $\mathrm{M}, \mathrm{M}$ \\
& $1 \times 10^{-3}$ & $\mathrm{D}, \mathrm{D}$ & $\mathrm{D}, \mathrm{D}$ & $\mathrm{D}, \mathrm{D}$ \\
& $1 \times 10^{-4}$ & $\mathrm{D}, \mathrm{D}$ & $\mathrm{D}, \mathrm{M}$ & $\mathrm{D}, \mathrm{D}$ \\
& $0.3 \times 10^{-4}$ & $\mathrm{M}, \mathrm{M}$ & $\mathrm{S}, \mathrm{S}$ & $\mathrm{S}, \mathrm{S}$ \\
\hline
\end{tabular}

maintained its original toxicity after incubation for $8 \mathrm{~h}$. The $12 \mathrm{~S}$ and $7 \mathrm{~S}$ toxins were partially inactivated, but they still possessed more than $33 \%$ of their original toxicity after $8 \mathrm{~h}$ exposure to the digestive juice.

\section{DISCUSSION}

Binding and absorption of the purified 16S (HApositive), $12 \mathrm{~S}$ (HA-negative) and $7 \mathrm{~S}$ (neurotoxin) forms of type $C$ botulinum toxin in the small intestine of the guinea pig were studied. Binding of toxin was observed in two different systems, namely in vivo and in vitro tests. We used the in vivo test to investigate the binding of toxin in as native a state as possible, and the in vitro test to confirm the detailed binding properties by employing inhibition tests with anti-toxin antibodies and neuraminidase treatment of cells. The results (Table 1) indicated that neither the neurotoxin ( $7 S$ ) nor the non-toxic non-HA exhibited specific binding to the small intestine, whereas the HA of the $16 \mathrm{~S}$ toxin did. In the in vivo test, binding of the $16 \mathrm{~S}$ toxin could also be detected by using anti-neurotoxin antiserum. This result implies that the neurotoxin is not dissociated from the $16 \mathrm{~S}$ toxin in the small intestine in the presence of intestinal juice, just as observed in the rat (Sugii et al., 1977a), and that the HA moiety anchors the neurotoxin on the epithelial cells of the small intestine. The optimum concentration of the $16 \mathrm{~S}$ toxin was tenfold lower in the in vitro test $(2 \mathrm{nM})$ compared with the in vivo test $(20 \mathrm{nM})$. This finding is reasonable because in the in vivo test, dilution of the toxin by the intestinal juice may occur and also the mucus layer may interfere in the binding of toxin to the microvilli. Binding of the $16 \mathrm{~S}$ toxin was inhibited by polyclonal antibodies against both the $16 \mathrm{~S}$ toxin and the non-toxic components, but not by the anti-neurotoxin antibody. Binding was also inhibited by treating the intestinal tissue sections with neuraminidase before addition of the $16 \mathrm{~S}$ toxin. From these results, we conclude that the HA of $16 \mathrm{~S}$ toxin is involved in the binding, and that terminal sialic acid residues of the membrane-bound glycoconjugates (glycolipids or glycoproteins or both) are important for binding.

We employed PLP fixative for the in vivo binding test because intense binding of the $16 \mathrm{~S}$ toxin was observed in the case of PLP fixative, but there was weak binding in the case of the paraformaldehyde fixative. PLP fixes both carbohydrate and protein, whereas paraformaldehyde fixes only the protein moiety. Although the reason for the above-mentioned phenomenon may not be answered until the toxin receptor structure is identified, it seems that the $16 \mathrm{~S}$ toxin, which bound to the carbohydrate chains of glycolipids in the membrane, is detached from the cells during dehydration with ethanol in the case of the paraformaldehyde fixative. In contrast, in the in vitro binding test, the degree of toxin binding was not so different between the PLP-fixed and paraformaldehyde-fixed preparations. The reason for this was not clear either, but we employed paraformaldehyde because we wanted to observe the binding of toxin to the carbohydrate chain in a chemically nonmodified form.

In the in vivo experiment, the $16 \mathrm{~S}$ toxin bound more strongly to the epithelial surface of the upper region than to that of the lower region of the small intestine. This is consistent with the previous findings, namely that the orally ingested botulinum toxin is absorbed mostly from the upper small intestine (Sugii et al., 1977 b). However, in the in vitro experiments with paraformaldehyde-fixed normal tissue sections, the $16 \mathrm{~S}$ toxin bound uniformly to the lower small intestine as well as to the upper region. This difference might be caused by the mucus layer overlying the intestinal epithelium. The nature of the mucus layer of the upper and lower small intestine may be somewhat different. It is possible that the mucus layer of the lower small intestine may inhibit the binding of $16 \mathrm{~S}$ toxin to the brush border only in the in vivo experiment, and that this mucus layer is washed out during the preparation of the pre-fixed sections for the in vitro experiment. Further experiments will be needed to define the role of the mucus layer in binding of the $16 \mathrm{~S}$ toxin to the brush border of the upper and lower small intestine.

To clarify the role of the non-toxic components in the intestinal absorption of the toxin, we injected the $16 \mathrm{~S}$, $12 \mathrm{~S}$ and $7 \mathrm{~S}$ toxin preparations directly into the small intestine without ligation. The absorption rate of the $16 \mathrm{~S}$ toxin, estimated by the toxicity of the sera from guinea pigs $8 \mathrm{~h}$ after toxin administration, was at least 100 -fold higher than those of the 125 and 75 toxins. However, the toxicities of the $7 \mathrm{~S}$ and $12 \mathrm{~S}$ toxins were not considerably decreased by incubating them with guinea pig digestive juice when compared with that of the $16 \mathrm{~S}$ toxin, the $7 \mathrm{~S}$ and $12 \mathrm{~S}$ toxins retaining at least $33 \%$ of their toxicity. These findings indicate that the 
reason for little binding and absorption of the $12 \mathrm{~S}$ and $7 \mathrm{~S}$ toxins is not that they are destroyed by the digestive juice but that they lack the HA. The HA may have a critical role in the binding and then the efficient absorption of the toxin. The HA moiety consists of four different subunits, namely HA-53, HA-33, HA-22-23 and $\mathrm{HA}-17$, non-covalently associated in the ratio 1:2:1:1 (Fujinaga et al., 1994; Inoue et al., 1996). Further research to determine how the $16 \mathrm{~S}$ toxin is translocated from the epithelial surface to the circulation and which subcomponent(s) of the HA is(are) required for binding and absorption is now being undertaken.

It has been reported that the type $\mathrm{C} 12 \mathrm{~S}$ toxin also has oral toxicity, although very low compared with that of the 16 S toxin (Ohishi \& Sakaguchi, 1980). We think that the low oral toxicity of the $12 \mathrm{~S}$ toxin may be caused by its low binding affinity to the epithelial cells of the small intestine rather than its lower resistance to digestive juice in the case of the guinea pig. In our experiment, binding of the $12 \mathrm{~S}$ toxin to the cells was hardly observed, and the guinea pigs showed no symptoms of botulism $8 \mathrm{~h}$ after injection of the $12 \mathrm{~S}$ toxin. Observations of duration longer than $8 \mathrm{~h}$ and autoradiography of the animals injected with isotope-labelled toxins may be needed to clarify the oral toxicity of the $12 \mathrm{~S}$ toxin. In type $\mathrm{E}$ and $\mathrm{F}$ botulinum toxins, only HA-negative $12 \mathrm{~S}$ toxins are produced. The oral toxicity of $\mathrm{E}$ and $\mathrm{F}$ toxins is also low (similar level to type C $12 \mathrm{~S}$ toxin) compared with type C 16S toxin (Ohishi \& Sakaguchi, 1980); the binding of type $\mathrm{E}$ and $\mathrm{F}$ toxins to the epithelial cells of the small intestine may also be low. The detailed absorption mechanism of these $12 \mathrm{~S}$ toxins, including types $\mathrm{E}$ and $\mathrm{F}$, should be studied.

\section{ACKNOWLEDGEMENTS}

This work was supported in part by grants 08457088 and 08770192 from the Ministry of Education of Japan.

\section{REFERENCES}

Caldero, J., Campo, E., Calomarde, X. \& Torra, M. (1988). Distribution and changes in glycoconjugates in rat colonic mucosa during development. Histochemistry 90, 261-270.

Fujinaga, Y., Inoue, K., Shimazaki, S., Tomochika, K., Tsuzuki, K., Fujii, N., Watanabe, T., Ohyama, T., Takeshi, K., Inoue, K. \& Oguma, K. (1994). Molecular construction of Clostridium botulinum type $\mathrm{C}$ progenitor toxin and its gene organization. Biochem Biophys Res Commun 205, 1291-1298.

Fujita, R., Fujinaga, Y., Inoue, K., Nakajima, H., Kumon, H. \& Oguma, K. (1995). Molecular characterization of two forms of nontoxic-nonhemagglutinin components of Clostridium botulinum type A progenitor toxins. FEBS Lett 376, 41-44.

Hauser, D., Eklund, M. W., Boquet, P. \& Popoff, M. R. (1994). Organisation of the botulinum neurotoxin $\mathrm{C} 1$ gene and its associated non-toxic protein genes in Clostridium botulinum C468. Mol Gen Genet 243, 631-640.
Henderson, I., Whelan, S. M., Davis, T. O. \& Minton, N. P. (1996). Genetic characterisation of the botulinum toxin complex of Clostridium botulinum strain NCTC 2916. FEMS Microbiol Lett 140, 151-158.

Inoue, K., Fujinaga, Y., Watanabe, T., Ohyama, T., Takeshi, K., Moriishi, K., Nakajima, H., Inoue, K. \& Oguma, K. (1996). Molecular composition of Clostridium botulinum type A progenitor toxins. Infect Immun 64, 1589-1594.

Kimura, K., Fujii, N., Tsuzuki, K., Murakami, T., Indoh, T., Yokosawa, N., Takeshi, K., Syuto, B. \& Oguma, K. (1990). The complete nucleotide sequence of the gene coding for botulinum type $\mathrm{C} 1$ toxin in the C-ST phage genome. Biochem Biophys Res Commun 171, 1304-1311.

Minton, N. P. (1995). Molecular genetics of clostridial neurotoxins. Curr Top Microbiol Immunol 95, 161-194.

Oguma, K., Syuto, B., lida, H. \& Kubo, S. (1980). Antigenic similarity of toxins produced by Clostridium botulinum type C and D strains. Infect Immun 30, 656-660.

Oguma, K., Fujinaga, Y. \& Inoue, K. (1995). Structure and function of Clostridium botulinum toxins. Microbiol Immunol 39, 161168.

Ohishi, I. \& Sakaguchi, G. (1980). Oral toxicities of Clostridium botulinum type $\mathrm{C}$ and $\mathrm{D}$ toxins of different molecular sizes. Infect Immun 28, 303-309.

Ohyama, T., Watanabe, T., Fujinaga, Y., Inoue, K., Sunagawa, H., Fujii, N., Inoue, K. \& Oguma, K. (1995). Characterization of nontoxic-nonhemagglutinin component of two types of progenitor toxin ( $\mathrm{M}$ and $\mathrm{L}$ ) produced by Clostridium botulinum type D CB-16. Microbiol Immunol 39, 457-465.

Sugii, S., Ohishi, I. \& Sakaguchi, G. (1977a). Correlation between oral toxicity and in vitro stability of Clostridium botulinum type $\mathrm{A}$ and $\mathrm{B}$ toxins of different molecular sizes. Infect Immun 16, 910-914.

Sugii, S., Ohishi, I. \& Sakaguchi, G. (1977b). Intestinal absorption of botulinum toxins of different molecular sizes in rats. Infect Immun 17, 491-496.

Tsuzuki, K., Yokosawa, N., Syuto, B., Ohishi, I., Fujii, N., Kimura, K. \& Oguma, K. (1988). Establishment of a monoclonal antibody recognizing an antigenic site common to Clostridium botulinum type B, C1, D, and E toxins and tetanus toxin. Infect Immun 56, 868-902.

Tsuzuki, K., Kimura, K., Fujii, N., Yokosawa, N., Indoh, T., Murakami, T. \& Oguma, K. (1990). Cloning and complete nucleotide sequence of the gene for the main component of hemagglutinin produced by Clostridium botulinum type C. Infect Immun 58, 3173-3177.

Tsuzuki, K., Kimura, K., Fujii, N., Yokosawa, N. \& Oguma, K. (1992). The complete nucleotide sequence of the gene coding for the nontoxic-nonhemagglutinin component of Clostridium botulinum type $\mathrm{C}$ progenitor toxin. Biochem Biophys Res Commun 183, 1273-1279.

Yoshimura, S., Komatsu, N. \& Watanabe, K. (1980). Purification and immunohistochemical localization of rat liver glutathione peroxidase. Biochim Biophys Acta 621, 130-137.

Received 12 March 1997; revised 23 July 1997; accepted 28 August 1997. 